\title{
Ungdomars erfarenheter som resurs för hållbar utveckling Om utbildning för hållbar utveckling och religionskunskaps- ämnet i gymnasieskolan
}

\section{Av Ulrika Svalfors}

Denna artikel diskuterar hur ungdomars egna erfarenheter kan användas som en resurs $i$ undervisning för hållbar utveckling inom religionskunskapen. Diskussionen sker mot bakgrund av en intervjustudie bland sistaårselever på fyra gymnasieskolor i Sverige. I dessa intervjuer framkommer det att ungdomar har gedigna erfarenheter av såväl engagemang som makt och uthållighet som är så pass integrerade med ungdomars uppfattningar om sig själva att de kan betraktas som delar av deras livsåskådning. Dessa erfarenheter kan därmed utgöra en resurs i undervisning om hållbar utveckling, vilket blir tydligt i religionskunskapen. Hållbar utveckling är ett tema som kan bidra till att stärka elevernas hermeneutiska förmåga och till mångfald - centralt för religionskunskapen och nödvändigt för en hållbar utveckling.

Nyckelord: ungdomar, livsåskådning, religionskunskap, hermeneutisk förmåga, engagemang, makt, uthållighet, utbildning för hållbar utveckling, gymnasieskolan, Sverige

ULRIKA SVALFORS (f. 1965), pedagogisk utvecklare ved Uppsala universitet. Box 2136, 75002 Uppsala.

E-post: ulrika.svalfors@uadm.uu.se.

\section{INTRODUKTION}

I Sverige har hållbar utveckling varit en del av grundskolans och gymnasieskolans riktlinjer sedan 1980-talet. En av många aspekter av hållbarhet som gör ämnet angeläget för skolan handlar om människors förmåga att leva tillsammans (Illisko, Skrinda and Micule 2014). Denna förmåga är intimt sammanvävd med enskilda människors och gruppers förmåga att förstå och praktisera mångfald (Jackson 2016, UNESCO 2017), vilket i sin tur kräver medvetenhet om egna värderingar i relation till tidigare erfarenheter (Jackson 1997).

Öhman \& Östman (2007) har visat att elevers tidigare erfarenheter spelar en viktig roll i olika faser av vad de kallar miljömoraliska lärprocesser. En miljömoralisk process startar när en situation kräver att eleven tar ställning och handlar på ett specifikt sätt för att bidra till hållbar utveckling, t ex tar med förbrukade batterier till sopstationen istället för att kasta dem i skogen. De menar att det är viktigt att få kunskap om ungdomars miljömoraliska erfarenheter

Prismet - IKO-Forlaget 2018

Tilgjengelig på https://journals.uio.no/index.php/prismet. Publisert under CC BY-NC 4.0. Fagfellevurdert 
och de attityder och det engagemang som är kopplade till dessa, för att kunna anpassa undervisningen till enskilda individer och därmed göra undervisningen för hållbar utveckling (Education for Sustainable Development - ESD) begriplig, relevant och meningsfull för elever.

Mot bakgrund av deras forskning vill jag pröva om inte också andra erfarenheter än strikt miljömoraliska kan bidra till att hållbar utveckling blir begriplig och meningsfull och därmed också utgöra ett substantiellt bidrag till ESD på gymnasiet. Rickinsons (2001) genomgång av mer än 20 undersökningar från Asien, Australien, Europa och USA visar att elever framförallt är bekymrade över globala miljöproblem, men konstaterar att det saknas empiriskt belagda kopplingar mellan denna oro och andra frågor som eleverna tycker är viktiga.

Denna studie vill bidra med kunskap om sådana kopplingar genom att granska ungdomars värderingar som framträder i berättelser om deras vardagsliv och som överlappar med en del av förutsättningarna för en hållbar utveckling. Det övergripande syftet med denna artikel är således att undersöka erfarenheter hos gymnasieungdomar som en resurs för lärandet om hållbar utveckling och knyta dessa specifikt till skolans religionskunskapsundervisning.

\section{BAKGRUND OCH TIDIGARE FORSKNING}

Hållbar utveckling tillhör värdegrunden för både grundskolan och gymnasieskolan i Sverige. Mellan de två nivåerna i skolsystemet finns en tydlig progression - från att «ha kunskap om» förutsättningar för hållbar utveckling (Lgr11) till att kunna «analysera människans samspel med sin omvärld utifrån perspektivet hållbar utveckling» (Lgy11). I grundskolan ingår kopplingen mellan värderingar och en hållbar utveckling i kursplanen för religionskunskap (Religionskunskap Lgr11), men inte i gymnasieskolan (Religionskunskap Lgy11). Förutsättningar för att åstadkomma en sådan koppling finns dock inom forskningsfälten utbildning för hållbar utveckling (ESD), ungdomars livsåskådningar och religionsdidaktik (RE).

Inom ESD-fältet konstaterar Rickinson, Lundholm och Hopwood (2009) att känslor och värderingar kan utgöra ett hinder för miljölärande hos gymnasieelever inom ESD. Om känslorna är starka kan det leda till att eleven utestänger innehållet i undervisningen och blir oengagerad, vilket i sin tur försvårar lärandeprocessen (s. 49). Ojala (2016) visar dock att känslan av oro inte bara är negativ för lärandeprocesser utan också kan utgöra en positiv resurs. Gymnasieelever förhandlar nämligen om etik och hållbar utveckling genom att relatera miljöfrågor till sina egna livshistorier på ett sätt som speglar bredare berättelser i samhället (Lundegård 2007). Figueroa \& Mills (2003) och Warren (2000) menar vidare att det finns tydliga samband mellan processer för hållbar utveckling och processer som har med livsåskådningar och maktrelationer att göra. 
När det gäller livsåskådningsforskningen menar Lövheim (2012) att frågor kring ungas (16-24 år) värderingar ofta har hållits isär från frågor som rör ungas livsstil och engagemang. Forskare som försökt överbrygga detta glapp har dock kunnat påvisa ett positivt samband mellan ungdomars livsåskådningar och en känsla av tillhörighet och delaktighet i det civila samhället (Collins-Mayo \& Dandelion 2010, Karlsson Minganti 2007, Smith \& Lundquist Denton 2005, von Essen \& Grosse 2012).

I fältet religionsdidaktik och religionspedagogik (RE) menar Jackson (2016) att ungdomars egna erfarenheter av såväl religion som livsåskådningar utanför skolan är en viktig resurs för RE. Det menar också Löfstedt $(2011,2013)$ och hon lyfter begreppet «livsfrågor» som en möjlig ingång till undervisningen. Etnografiska studier av elevers konstruktioner av religion och livsåskådning i skolmiljön visar att mångkulturalitet både är en resurs och ett hinder för lärande (von Brömssen 2003), att elevernas livsåskådningar centreras runt jaget med betoning på att «vara sig själv» (Risenfors 2011).

Föreliggande studie bygger vidare på presenterad forskning som visat att ungas livsåskådningar kan utgöra en resurs för engagemang och att samtal om värderingar kan stödja lärandet om hållbar utveckling, där religionskunskapen har särskilt goda förutsättningar för att stimulera ett sådant lärande genom sin tydliga koppling mellan värderingar och livsåskådningar.

\section{TeOretisk RAM}

I studien utgör religionsdidaktik tillsammans med livsåskådningsbegreppet den teoretiska ramen. För att skapa förutsättningar för mångfald och respekt i religionskunskapen betonar Jackson (1997:69) vikten av att lyfta fram personliga erfarenheter i undervisningen. Genom att utforska hur egna värden «överlappar» andras värden blir religionskunskapsundervisningen ett forum för samtal och förhandlingar över religions- och livsåskådningsgränser (1997:91). Elever ges då möjlighet att öva upp sin hermeneutiska förmåga genom att medvetandegöra sig om och omvärdera sin egen världsbild; genom att uppmuntras inta en kritisk distans till frågan som behandlas; och genom att få stöd i att utveckla kritisk distans till tolkningsprocessen. (Jackson 2016:157)

Erfarenheter och värden blir på så vis en ingång till att problematisera både den egna och andras livsåskådningar. Det livsåskådningsbegreppet försöker fănga är att människan tenderar att systematisera sina idéer och värderingar till en meningsfull och sammanhängande helhet (livsåskådning) när hon skapar mening utifrån erfarenheter (Lindfelt 2003:82, Bråkenhielm et. al. 2013:16). En livsåskådning består emellertid inte på ett entydigt sätt av individens teoretiska föreställningar som ger vägledning och inspiration, utan konstrueras med politiska och ideologiska förtecken där värderingar blir tätt sammanvävda med 
normer och makt (Martinson 2013:52-53, Foucault 1971/1993).

I denna studie innebär etik reflektion över moralen, dvs. reflektion över egna och andras handlingar och ställningstaganden i relation till det goda samhället (Collste 2010:20, Löfstedt 2011:120). När värden framträder i informantens erfarenheter gör de det som en form av normer som reglerar handlingar (moral). Med hållbar utveckling avses en utveckling som innebär att dagens behov kan tillgodoses utan att äventyra kommande generationers möjligheter att tillgodose sina behov (WCED 1987). Hållbar utveckling rör tre dimensioner: den miljömässiga, den sociala och den ekonomiska (Agenda 2030).

\section{Metod}

Tre erfarenheter (tillika värden) hos ungdomarna som jag vill pröva att relatera till hållbar utveckling är engagemang, påverkansmöjligheter och uthållighet. Dessa tre faktorer är konstitutiva för hållbar utveckling. De är nödvändiga förutsättningar för att en utveckling ska kunna bli hållbar. Andra faktorer är t ex kunskap om klimatförändring och jämställdhet, förmåga att förstå kulturell mångfald samt att kunna problematisera konsumtion (UNESCO 2017). Valet av de tre erfarenheterna grundar sig i tidigare forskning som visat att unga människors livsåskådningar kan utgöra en resurs för delaktighet (engagemang) i samhällsfrågor och stimulera dem till att vilja vara med och påverka utveckling (se Collins-Mayo \& Dandelion 2010, Karlsson Minganti 2007, Smith \& Lundquist Denton 2005, von Essen \& Grosse 2012 ovan).

Prövandet av dessa tre erfarenheter sker genom halvstrukturerade livsvärldsintervjuer, en metod som bygger på fenomenologisk teori (Kvale \& Brinkmann 2014:44f). Sådana intervjuer försöker fånga in intervjupersonens erfarenheter och värderingar genom att personen själv får tolka innehållet i olika fenomen.

Våren 2012 genomfördes därför 14 halvstrukturerade livsvärldsintervjuer med elever ${ }^{1}$ som gick sista terminen på gymnasiet. Intervjuerna ägde rum i ett avskilt rum på elevernas skola. Intervjuerna spelades in med hjälp av en diktafon och transkriberades ord för ord i sin helhet. Informanter anges med bokstav (beteckning för viss skola) och ett nummer för att göra intervjuerna unika.

Själva intervjun startade med att jag berättade om mig själv och om det större projektet som intervjuerna ingick i (Preconditions of environmental moral learning within education for sustainable development: A multidisciplinary study of young Swedes' attitudes, commitments and actions). Sedan fördes ett kort resonemang kring vad hållbar utveckling oftast innebär i stort.

Intervjun ramades på det här viset in av skolmiljön och hållbar utveckling som ett viktigt och aktuellt ämne, men intervjuerna handlade varken om under-

17 kvinnor varav 4 på studieförberedenade program och 3 på yrkesförberedande, samt 7 män varav 3 på studieförberedande program och 4 på yrkesförberedande. 
visning eller hållbar utveckling i första hand. Skolmiljön är emellertid viktig eftersom det är här som ungdomars erfarenheter ska tas tillvara. Själva rummet bidrog därmed indirekt till att koppla utgångspunkten (hållbar utveckling) och informanternas egna erfarenheter av engagemang till skolundervisning.

I intervjuerna fick ungdomarna berätta om sin vardag, hur den såg ut och vad de gjorde. I samband med deras berättelser ställde jag följdfrågor utifrån en intervjuguide vars syfte var att ta reda på vad som engagerade dem, vad de lade sin tid och energi på, vilka erfarenheter de har av uthållighet (tålamod), av att hushålla med resurser och vilka erfarenheter de har av att kunna påverka ett förlopp i en särskild riktning. På så vis fångades deras upplevelser och förståelse av engagemang, inflytande och uthållighet.

Sammanfattningsvis genomfördes studien i fem steg: 1) inläsning och operationalisering av engagemang, påverkansmöjligheter och uthållighet samt framtagande av intervjuguide 2) genomförande av intervjuer 3) transkribering av intervjuerna, kategorisering utifrån de tre erfarenheterna och kodning av texterna (Kvale \& Brinkmann 2014:243) 4) analys genom att utveckla, klargöra och utvidga vad som kommer till uttryck (Kvale \& Brinkmann 2014:233) 5) relatera resultat till tidigare forskning.

\section{Resultat}

Resultatet av analysen presenteras under de tre olika erfarenheterna (kategorierna) som står i fokus i studien. Under varje rubrik redovisas slutsatserna utifrån några valda citat $i$ intervjuerna. Citaten ska ses som illustrationer av hur ungdomarna förhåller sig till respektive kategori, inte som en uttömmande beskrivning av kategorins innehåll. Ambitionen är snarare att genom att läsa enskildheter i ljuset av alla intervjuer - sammanhanget (skolan) och den större inramningen (hållbar utveckling) - försöka tolka uttryck på ett sådant sätt att ungdomarnas egna berättelser kommer till sin rätt i så stor utsträckning som möjligt.

\section{Engagemang}

Det jag framförallt har sökt efter i materialet är uttryck för engagemang. När personen självmant uppehåller sig vid något tema, lägger ut texten och orden skapar ett naturligt energifyllt flöde så har jag uppfattat det som att vad personen talar om engagerar hen. När en person ger uttryck för sådant engagemang i relation till något som hen regelbundet väljer att ägna sig åt så har det tolkats som engagemang i linje med vad denna studie ämnar förstå. Innebörden i engagemang har på så vis mejslats ut både genom direkta frågor och genom en kodning enligt denna förståelse.

Intervjuerna visar att ungdomarna är engagerade och vill vara engagerade. Att engagera sig innebär att ta sig tid för det hen tycker är viktigt, att ge av sig 
själv och vara uthållig i det:

- Vad innebär det att vara engagerad för dig?

- Ja ... att man tar sig tid och [att] man ger av sig själv till det man ... till det man vill ska hålla liksom (Foo1)

Informanten tänker medan hen talar, därav tankepunkterna. Så ser alla transkriberingar ut. Eleverna tänker ofta efter och i detta eftertänksamma relaterar de till sitt eget liv. De gräver i sitt minne och vecklar ut det levda livet framför intervjuaren i en tolkad version för situationen (i samspel med kontexten). I det mötet uppstår förståelse för det vi talar om. Citatet visar att engagemang uppfattas handla om att prioritera något före något annat. Det innebär att inte allt kan betraktas som engagemang, utan engagemang är något som tar tid $i$ anspråk och som på så vis kräver att personen väljer bort annat. Ett uttryck för det är att «brinna för» det en engagerar sig i. (F003) En annan informant beskriver det stora engagemanget hos en tränare i termer av att hen lade ner «all sin tid på oss». (Fo04) Men tid är inte allt. Engagemang innebär också att «man ger av sig själv till det man vill ska hålla» enligt citatet ovan. Självutgivande och hållbarhet blir på så vis konstitutivt för engagemang, utöver tid och att avstå från annat. Underförstått finns också valfriheten, engagemang handlar om att kunna välja vad en engagerar sig $i$ - annars kan vi inte tala om «att ta sig tid».

Trots att valfriheten är en ofrånkomlig del av engagemang så problematiserar några informanter denna valfrihet. En informant berättar $\mathrm{t}$ ex om de många ofrivilliga situationer som en medfödd sjukdom försatt hen i (Vo03). Valfriheten är trots allt inte så stor, utan mycket är «förutbestämt» som en informant uttrycker det:

- Och sen så är det ju liksom ... bestämt att jag kanske ska plugga efter det och sen ska jag jobba och sen ska [jag] bli pensionär och sen ska jag dö. Mitt liv är ju någonstans redan förutbestämt allting och då vill jag liksom att man ska kunna ... under det som man ... som redan är bestämt så ska man i alla fall kunna ... leva sitt eget liv ... någorlunda sett som man själv vill liksom ... och inte bara ... göra som den stora planen ... (Voo4)

Just den här eleven var mycket politiskt engagerad vilket kan betraktas som ett tydligt val inom ramen för det som inte går att påverka, «den stora planen». Det visar återigen att engagemang har med val att göra, men det får också en klang av drivkraft och att inte låta omständigheter ta över. Engagemang blir ett uttryck för individualitet och hopp.

Varför engagerar sig eleverna? Många vittnar om att de mår bra av att engagera sig. En informant ägnade mycket av sin fritid till dans, både att dansa själv och att vara danslärare. Hen kunde lägga flera timmar på dans varje dag, men menade att det inte tröttade ut hen: 
- Jag tror det, alltså, det är ... man blir liksom piggare och gladare och då när jag kommer hem så kan man tro att jag är jättetrött, men då kan jag faktiskt sätta mig ner och göra alla läxor och så för jag är ändå så här pigg och glad och har energi (Foo3)

Engagemang ger med andra ord energi, vilket flera vittnar om. Det finns också resonemang som drar åt andra hållet - att bli för engagerad dränerar på energi. (V003) Informanten som dansar menar dock att engagemanget också gav hen tålamod och uthållighet. Den kopplingen mellan engagemang och tålamod gör flera informanter. Vad som driver ungdomarna är många gånger viljan att göra skillnad för andra:

- ... men jag tycker om att hjälpa, jag vill hjälpa människor att leva bättre (Foo2)

- ... jag drivs egentligen av att ... jag vill göra skillnad för andra människor (Voo3)

Att engagemang också handlar om att göra det bättre för andra är något som återkommer i intervjuerna. En informant beskriver hur hen «kan sitta i flera timmar med vissa människor ... och försöka [få dem att] ... känna att jag är där» (F004) och en annan att hen fanns hos sin kompis när «han mådde som sämst» (V001). Andra berättelser handlar om att värdesätta kärlek och omsorg högre än pengar på en arbetsplats (F006) och om att finnas för äldre som «har byggt upp vårt samhälle» (L001). Därmed blir engagemang uttryck för en form av transcendens - att överskrida sin egen person och sitt egenintresse. Engagemang är också uttryck för solidaritet. Det handlar i relativt stor utsträckning om att engagera sig i kompisar och familj, som i följande fall:

- Men om man ser liksom att det är någonting liksom ... [som] inte är rätt, då är det

klart liksom att man ... säger till ... oftast ... (Foo5)

En del av informanterna uttrycker med andra ord ett rättspatos i samband med vad de vill engagera sig för. Ett rättspatos som sträcker sig över samhället i stort och till och med världen i sin helhet, $\mathrm{t}$ ex i önskan om att utföra volontärarbete (Fo01) eller ett politiskt engagemang för globala frågor som hållbar utveckling. (Voo4)

Långsiktiga mål tycks inte alltid vara relevant när det gäller ungdomarnas engagemang, en viss otålighet kan skönjas i förhållningssättet. En del engagerar sig så länge de kan se att det ger resultat relativt snabbt:

- Men det blir ändå så här att, jag vet inte ... eehh om man inte engagerar sig, det känns, alltså ibland blir det bara att man inte orkar liksom (Foo1)

Något som är relaterat till solidaritetstanken är att engagemang också kan innebära att hen tar ett steg tillbaka och släpper fram andra och endast bidrar vid väl valda tillfällen. Det kan dels handla om att göra det möjligt för andra att 
engagera sig på sitt sätt (solidaritet) (Vo02), dels att hushålla med egen energi (F002). I stort förknippas dock engagemang framförallt med att vara aktiv, att ta initiativ och driva något. Engagemang uppfattades genomgående som något positivt.

\section{Sammanfattning engagemang}

I informanternas livsvärldar konstrueras engagemang som något positivt, ett värde som uppfattas komma inifrån ungdomarna själva. Drivkraften i engagemanget ligger i att forma sitt eget liv och att finnas för andra. Transcendensen blir på så vis en förutsättning för immanensen och vice versa. Engagemang handlar om att välja bort somligt för att få energi genom att befinna sig i det som går utöver en själv. Självutgivande, hållbarhet och valfrihet är andra konstitutiva delar av engagemanget. Detta blir ett uttryck för individualitet och hopp i ungdomarnas livsvärldar. Engagemang skapar mening. Det är produktivt - ungdomarna blir till i transcendensen. Det är repressivt - engagemanget driver dem längre än orken räcker och kräver ett åtsidosättande av dem själva (immanensen) som ibland blir negativt.

\section{Påverkansmöjligheter}

Erfarenheter av makt är det andra som studien försöker fånga i ungdomars livsvärldar. Här har jag kallat det för påverkansmöjligheter - känslan av att kunna påverka ett förlopp i en särskild riktning. I kodningen av materialet har jag tittat efter uttryck som rör inflytande, styrning och närliggande teman för att försöka fånga innebörden i makt. Men jag har också intresserat mig för uttryck av motsatsen, som maktlöshet eller känslan av uppgivenhet.

I stort sett alla ungdomar ger uttryck för att de kan påverka, indirekt eller mer direkt. En informant kopplar inflytande till ett samhällsengagemang och önskan att påverka mer allmänna strukturer än på ett personligt plan: «någonstans så känns det att jag ... skulle kunna påverka ... samhället i stort» (V004). De flesta kopplar dock påverkansmöjligheter till en privat nivå och menar sig ha ganska stort inflytande över olika beslutsprocesser på den nivån:

- Jag vet i min familj är jag, har jag i alla fall ganska stort inflytande känns det som ...

det känns som om vi ... allihop liksom har lika stort inflytande (Foo1)

Citatet ger uttryck för en demokratisk hållning; alla har lika stort inflytande över det som sker privat. En sådan upplevelse av delaktighet i den mest grundläggande delen av livet bildar en bas i ungdomarnas livsvärld som i sin tur möjliggör tron på inflytande i vidare cirklar. Huruvida de upplevde sig ha möjligheter att påverka i skolan eller inte berodde till stor del på lärarna, men få beskriver sig som maktlösa i det sammanhanget. 
Övervägande många vill också utbilda sig till yrken där de kan påverka:

- Jag vill gärna jobba med mänskliga rättigheter ... nåt ... samhällsvetenskapligt ... internationella relationer är också ... rättsvetenskap eller ... kanske psykologi och såna saker också (Voo5)

Det är ganska stor skillnad på att läsa juridik och psykologi, men resonemanget handlar inte i första hand om yrkesval. Det är det som gör det intressant och illustrativt för hur informanterna förhåller sig till maktfrågan på ett övergripande plan. Vad eleven ger uttryck för är i första hand önskan att få ett reellt inflytande över samhällsutvecklingen, att kunna göra livet lite bättre för fler. Om det sedan sker i form av juridik eller psykologi är av underordnad betydelse, eller som en annan informant uttrycker det: «jag vill ju ha någonting [...] som betyder något [...] för mig och för omgivningen» (Fo02). Informanten ovan beskriver denna önskan också $\mathrm{i}$ termer av jämlikhet: «när folk verkligen lider ... [...] så kan det ju inte vara ... tänker jag» (Vo05). De är ambivalenta inför möjligheten att kunna påverka på ett större plan, men ger uttryck för ett patos som driver dem att utbilda sig till ett yrke som gör skillnad. Det kan förstås som en bearbetning av deras egen makt i relation till en komplex värld.

Innebörden i makt kommer också fram i upplevelse av frånvaro av makt eller inflytande. Ett genomgående tema i intervjuerna när det gäller makt är därför också frustration. Ungdomarna uttrycker frustration när det inte går att påverka i den riktning som de önskar. En informant berättade hur hen försökte få ett band att träffas och repa, men till slut gav hen upp eftersom de andra mest verkade uttråkade. (§̊o01) Ett annat exempel på frustrerande situationer är när grupparbeten inte fungerar, ett tema som också återkommer i intervjuerna. Följande citat är en utläggning av hur det blir för informanten när någon styr väldigt mycket och visar hur inflytande hänger tätt samman med engagemang och uthållighet:

- Jag tappar intresset för det vi gör ... lite så här, men jag kan typ ... [...] jag gör det, men jag gör det inte så här, jag engagerar mig inte så mycket $i$ det, så att jag känner att jag inte ... det känns som att det, ja men då är det hennes projekt, då får hon liksom styra och då gör jag bara det jag [måste] [...] Jag tycker att jag gör ett sämre arbete (Foo2)

Upplevelsen av att någon inte lyssnar, utan enbart är intresserad av att driva igenom sin egen uppfattning har menlig inverkan på engagemanget. I det här fallet valde eleven inte att kämpa om makten. Varför säger inte materialet, men exemplet är illustrativt för skörheten i engagemang och att det tycks kräva någon form av ömsesidighet. Samma typ av frustration ger informanterna uttryck för när de inte blir tagna på allvar på grund av sin ålder; när vuxna inte litar på dem på grund av att de är just ungdomar: «... man kan känna ibland att folk inte 
tar en på allvar för att de tycker att man är ett barn ... bara för att ens förälder säger någonting så är det sant. Och bara för att jag säger någonting så är det inte sant» (F003). Den typen av erfarenhet bidrar till upplevelsen av maktlöshet och därmed också icke-engagemang och i värsta fall uppgivenhet.

Att kunna samtala med dem som en ska arbeta tillsammans med är ett tema som också återkommer i intervjuerna. Det ska inte förstås som att andra behöver tycka likadant som en själv. Tvärtom. I så fall skulle det inte finnas så mycket att diskutera. Det handlar om att alla ska få säga sitt och att eventuellt komma fram till någon kompromiss: «då får alla säga sina idéer och så gör ... kommer man fram till något ... nån kompromiss » (V005). Det innebär också att ge utrymme för andra om en själv blir ledande i arbetet:

- Ibland så känns det ändå som att man kommer i en grupp där, alltså, då går det att ... att ta plats och så där, göra det man ska och så ... och då kan man till exempel bli lite som en ledare, men ... då gäller det också att ... inkludera alla och så där ... [...] När jag väl tar plats så ... då känns det som att jag ... drar in alla så här ... i ... [...] inte bara ta alla beslut så (Foo7)

Temat att ge utrymme för andra återkommer med andra ord här och skapar en länk till engagemang $i$ termer av att överskrida sig själv.

Känslan av maktlöshet är alla bekanta med om än i olika grad. Det handlar om lite olika saker. Det kan handla om känslan av maktlöshet när en inte kan prestera som tänkt: «man faller ju ändå ner i den där lilla luckan som man måste ta sig ut för [sic] när man börjar om igen» (Voo1). Det kan handla om att möta dominanta personer som gör det svårt att komma till sin rätt som i exemplet ovan (F002). Några informanter ger uttryck för maktlöshet i relation till normer och system. Ett exempel på det är en informant som var kritisk till hur antimobbningsarbetet var organiserat på grundskolan. Hen var kritisk till att hen som en av två kamratstödjare fick gå på föreläsning om en person som varit mobbad hela lågstadiet: «... då tänkte jag verkligen, varför går inte alla på den här? ... för att, det var inte vi som mobbade» (V005). Men maktlösheten kommer också till uttryck i förhållande till globala villkor: «jag tycker man kan känna sig maktlös ganska ofta ... rent allmänt bara, man tänker på liksom hur världen ser ut och typ så där» (Fo01). Vad som blir tydligt i alla berättelser är att engagemang är ett sätt att motverka känslan av maktlöshet.

En av eleverna berättade om ett extraarbete hen hade på ett café där hen trivdes väldigt bra, fram tills dess att caféet bytte ägare. Innan de nya ägarna beskriver hen en arbetsmiljö där alla hjälps åt och där hen har inflytande på ett konstruktivt sätt som ansvarig. De nya ägarna ändrar dock helt på upplevelsen:

- Men när de nya ägarna kom kunde de liksom kolla igenom ... [...] alltså efter dagens slut, att alt låg på rätt plats, att allt var rätt gjort. Inte bara kolla igenom kassan utan 
liksom ... de kollade allt annat, frysen och kylen och så ... Och var det minsta lilla fel liksom [enligt dem]... då var det ju jag som ... även fast jag inte visste vem som hade ... lagt någonting där eller så ... så var det liksom jag som fick, fick ta det ... och då är, då var man ju verkligen ... på helspänn hela dagen för att allt skulle gå rätt till liksom (Foo6)

Vad eleven beskriver är hur kontrollbehovet hos de nya ägarna fick hen att förlora tilltron till sig själv. Därmed blev hen mindre engagerad (valfriheten gick förlorad) och framförallt upplevde hen hur den egna uppfattningen minskade drastiskt $\mathrm{i}$ betydelse för arbetsgivaren. Det är inte uppgivenhet som präglar berättelsen, utan upplevelsen av maktlöshet. Hur hen än försökte («på helspänn hela dagen») så blev inte ägarna nöjda. Det slutade med att hen slutade på caféet, något som hen fortfarande sörjer.

\section{Sammanfattning påverkansmöjligheter}

Makt konstrueras i informanternas livsvärldar, det är något som alla ger uttryck för om än på olika sätt. Makt i relation till engagemang konstitueras av ömsesidighet, av kompromisser och förmågan att ge andra utrymme. Inflytande är viktigt för ungdomarna och kräver olikhet. Utan denna olikhet finns inget att diskutera och därmed inte heller upplevelsen av att göra skillnad genom att påverka i någon riktning. Maktlöshet konstrueras som frånvaro av röst, att ens egen uppfattning inte tillskrivs värde eller betydelse för det som pågår. Det meningsfulla i maktutövning handlar därför om att omvandla erfarenheter av maktlöshet till inflytande för sig själv och andra. Därmed konstrueras makt som ömsesidighet och en form av omsorg om allas möjlighet att bidra. Med en sådan förståelse blir makt något produktivt när den möjliggör olikhet och dialog. Repressiv blir makten när den kommer till uttryck i ensidighet, dominans och ignorans.

\section{Uthållighet}

Den sista erfarenheten jag intresserat mig för hos ungdomarna, är erfarenhet av att vara uthållig. Det har redan berörts tidigare och är tätt sammanvävt med såväl engagemang som påverkansmöjligheter. Ungdomarna berättar om viljan att vara tålmodig och situationer där uthålligheten varit en väsentlig del av engagemanget. I det här avsnittet lyfts ytterligare citat som illustrerar hur uthållighet konstrueras i ungdomarnas livsvärld.

Uthållighet är ett tema som återkommer hos informanterna, även när jag inte frågar efter det. Det handlar både om att vara uthållig för sin egen skull och för andras skull. Framförallt kommer temat upp i relation till andra. En av eleverna berättade om en vårdpraktik där hen mötte en mycket sjuk patient:

- Man kunde liksom se hennes ögon det här, hur ska jag säga, smärtan, den här jobbiga delen som hon ... alltså går igenom just nu. [...] Det krävs väldigt mycket tålamod (Loo1) 
Tålamodet rör en annan människas utsatthet, en utsatthet som kräver mycket arbete hos informanten. En annan informant uttrycker det i termer av att det handlar om att «tagga dom och inte ge upp ... nej, men du klarar det här!». (F003) I vårdpraktiken handlar det om ett fysiskt arbete med patienten, men ännu mer om ett mentalt arbete i och med den process som en annan människas påtagliga lidande sätter igång hos eleven. Detta mentala arbete innebär också att försöka väcka kämparglöd hos den sjuka och förmedla ett hopp.

Flera av ungdomarna lägger stor vikt vid att vara uthållig för andras skull. En informant berättar om kompisar som mår psykiskt dåligt i perioder:

- Jag brukar ju inte ge upp så mycket på människor även om det är sv[årt]. Jag är väldigt, jag har haft kompisar som jag ... som har mått riktigt, riktigt dåligt i perioder och jag har aldrig gett upp på dem, eller sagt, nej, men nu orkar jag inte med dig längre (Voo3)

Eleven har ett eget uttryck för uthållighet - «att inte ge upp på någon». Det kan förstås på flera sätt, men det anknyter i vilket fall till hopp. Uthållighet är berättelser om att inte ge upp, trots att mycket talar emot en positiv utveckling. Att inte ge upp trots att både tålamodet och orken kan tryta ( «nu orkar jag inte med dig längre»). En liknande berättelse vittnar om att uthållighet har med tid att göra, vilket knyter uthålligheten till engagemang:

- Jag kan sitta flera timmar med vissa människor ... och försöka hålla dem, liksom ... känna att jag är där för dem (Foo4)

Den situation eleven beskriver är mentalt krävande och förutsätter därmed uthållighet i engagemanget. Det uthålligheten bidrar med i relation till engagemang är just det svåra i situationen. Uthålligheten konstitueras av dåliga odds, skulle en kunna säga. Det är därmed ingen enkel sak att vara uthållig, vare sig för sin egen eller för andras skull.

Just detta faktum gör att det finns risk att orken tryter och därför är uthållighet förknippat med att hushålla med resurserna. Oron över att inte orka finns ständigt närvarande i berättelserna, och utgör en del av sviktande tilltro till egen förmåga. Informanten som talade om att «tagga» andra, var också påtagligt oroad för att inte orka:

- Om de [kompisarna] har något problem de vill prata om eller så, så hjälper jag alltid till ... även, jag försöker alltid vara tillgänglig och det ... Ibland så räcker man inte till och även fast jag vill göra det så... det kan bli, kan vara ganska pressande på mig också ... att jag vill verkligen ... vara allt för alla ... och det är ju svårt för mig (Foo3)

Från sidan kan det lätt se ut som att eleven har orimliga krav på sig själv. Att vara tillgänglig för alla kompisar hela tiden, är inte en rimlig hållning. Men det 
är vad engagemanget driver hen till. Uthålligheten konstrueras i så måtto av kompromisslöshet. Drivkraften är såtillvida inte bara en positiv drivkraft, utan kan också ta sig destruktiva uttryck. Detta trots den positiva konnotationen som uthållighet har i ungdomarnas berättelser («att inte ge upp på någon»). Denna tvetydighet är det som uthålligheten står för.

De som brottas med att inte räcka till för alla behov, brottas också med att kunna säga nej. «Nej» motiveras framförallt utifrån en förväntan på ömsesidighet. När ömsesidigheten uteblir uppfattas det som «otacksamt» och föranleder personen att ompröva engagemanget och säga «nej» nästa gång frågan om samarbete kommer (F002). I intervjuerna framkommer därmed en tydlig idé om att jämlikhet är nödvändig för uthålligheten. Inte så att varje gest måste återgäldas i stunden, men så att personen i det stora hela behöver uppleva att hen får stöd tillbaka när hen så behöver det. En variant på jämlikhet mellan två personer är när stödet kommer från en tredje part: «jag fick prata med [...] en lärare som [sa] 'ja, men försök att släppa allt, försök [...] [att] inte lägga dig alla andras liv' » (Vo02). Jämlikheten kan alltså tolkas på ett övergripande plan, men är oavsett nivå alltid knuten till ömsesidigheten i påverkansmöjligheterna. Det finns undantag från denna princip, som i exemplet från vårdpraktiken ovan (L001). Eleven ger där uttryck för viljan att finnas kvar vid patientens sida enbart utifrån smärtan i patientens ögon. Senare i intervjun framkommer dock att den uthållighet som eleven ger uttryck för är knuten till patientens relativt kravlösa kamp, till skillnad från «besvärliga» patienter som kräver det omöjliga av personalen. Uthålligheten tycks med andra ord vara en fråga om ömsesidiga ansträngningar (i termer av fysiska insatser respektive visad hänsyn) också här, även om situationen i sig är väldigt olik mer jämlika situationer som t ex grupparbeten i skolan.

Uthållighet handlar också, som sagt, om att vara uthållig för sin egen skull. Ett sådant intressant exempel är en elev som talar om att förvandla ett misslyckande till en sporre att göra nya försök:

- Ja, ibland så förlorar man tålamodet så här ... om det går dåligt och så där men ... man bara [...] hänga i alltså (Foo7

Informanten som tidigare beskrev hur hen «föll ner i en lucka» när hen inte uppnådde det betyg som hen tänkt sig (Voo1), svarar följande på min fråga hur hen tar sig vidare: «samma sak som ... tynger ner mig, [...] får mig att köra framåt» (V001). Det handlar om att «hänga i », även om det för stunden känns missmodigt. Det är överhuvudtaget väldigt slående hur mycket uthållighet som ungdomarnas berättelser ger uttryck för. Tålamod, uthållighet, att inte ge sig, är lika stora delar av deras livsvärld som engagemang och makt. 


\section{Sammanfattning uthållighet}

När det gäller uthållighet är det också konstitutivt för ungdomarnas livsvärld och starkt knutet till såväl engagemang som påverkansmöjligheter. Till skillnad från engagemang konstrueras emellertid uthållighet som något tvetydigt. Det står både för ett hoppfullt tålamod och för en destruktiv kompromisslöshet. Oro kringgärdar därför uthålligheten och ungdomarna förhandlar om dess betydelse. Emellanåt framstår det som ett absolut värde, emellanåt framställs det som ett relativt värde. Det senare inträffar framförallt om det uppfattas som att det inte är ett inslag i en större helhet präglad av jämlikhet. Om så inte är fallet, är det tillräckligt skäl för att inte vara uthållig utan ge upp. I ungdomarnas livsvärld konstitueras uthållighet av «dåliga odds» (kompromisslöshet och hotet om utmattning), och utgörs framförallt av såväl fysiskt som mentalt arbete som har riktning framåt mot en bättre tillvaro.

\section{Sammanfattring och diskussion}

Det övergripande syftet med denna studie är att undersöka erfarenheter hos gymnasieungdomar som en resurs för lärandet om hållbar utveckling och knyta dessa specifikt till skolans religionskunskapsundervisning. Studien bygger vidare på forskning som visat att ungas livsåskådningar kan utgöra en resurs för engagemang (Collins-Mayo \& Dandelion 2010, Karlsson Minganti 2007, Smith \& Lundquist Denton 2005, von Essen \& Grosse 2012) och att samtal om värderingar kan stödja lärandet om hållbar utveckling (Lundegård 2007, Figueroa \& Mills 2003, Warren 2000).

Ungdomars egna erfarenheter ger en ingång till att problematisera egna och andras livsåskådningar i undervisningen (jmf Löfstedt 2011, 2013), vilket övar upp elevernas hermeneutiska förmåga (Jackson 1997). Att öva upp denna förmåga är särskilt viktigt när det gäller hållbar utveckling, eftersom vi numera vet att en kritisk distans till den egna världsbilden och tolkningsprocessen (jmf Jackson 2016) är nödvändig om dagens behov ska kunna tillgodoses utan att äventyra kommande generationers behov (UNESCO 2017). Genom att få tillgång till ungas erfarenheter av konstitutiva delar av hållbar utveckling (engagemang, påverkansmöjligheter och uthållighet) kan alltså undervisningen för hållbar utveckling anpassas till enskilda individer och därmed blir den begriplig, relevant och meningsfull för dem (jmf Öhman \& Östman 2007).

Den intervjustudie som genomfördes bland gymnasieungdomar visar att engagemang konstrueras som ett positivt värde i deras livsvärldar, ett värde som ger uttryck för hopp och skapar mening. Men det är ändligt. Att finnas till hands för andra över tid kräver därför medvetna val. Det kräver också makt i form av möjlighet att påverka förloppets gång. Erfarenheter av maktlöshet har de flesta och det blir incitament till att försöka åstadkomma en förändring genom enga- 
gemang. Makt konstrueras i stort som ömsesidighet och en form av omsorg om allas bidrag, vilket möjliggör olikhet och dialog. Också uthållighet är konstitutivt för ungdomarnas livsvärld och starkt knutet till såväl engagemang som påverkansmöjligheter. När det gäller uthållighet förhandlar dock ungdomarna om dess innebörd eftersom de förhåller sig ambivalent till dess värde. För att vara uthålliga tycks ett mått av jämlikhet vara nödvändigt för ungdomarna, i alla fall motivationsmässigt. Uthålligheten består av fysiskt och mentalt arbete som syftar framåt och har en bättre tillvaro som mål.

Ungdomarna har alltså gedigna erfarenheter av engagemang, av att behöva vara uthålliga för andra, att hushålla med resurser hos både sig själva och andra, samt att försöka påverka. Framförallt tror de på samhörighet, jämlikhet och respekt. De är till och med beroende av detta för att känna mening och lust att arbeta för något. Dessa erfarenheter och tolkningar av engagemang, makt och uthållighet överlappar med innebörder och tolkningar av vad som krävs för att utvecklingen ska bli hållbar - de tillhör den sociala dimensionen av hållbar utveckling (UNESCO 2017). Ungdomar är med andra ord kompetenta och kunniga i konstitutiva delar av hållbar utveckling. Och mer än så, genom att dessa värden tillhör deras centrala värderingssystem utgör de också en vital del av deras livsåskådning (Bråkenhielm et al 2013). Vad ungdomarna uttrycker i intervjuerna är vad Lindgren et. al (2005) kallar för «interpersonal individualism», en sorts mellanmänsklig individualism. Ungdomarna tror på tillhörighet, de tror genom att tillhöra ett större sammanhang (Day 2009), men de gör det utifrån en stark individuell autonomi (jmf Risenfors 2011).

Dessa resultat ger viktig kunskap som kan användas i undervisningen för hållbar utveckling inom religionskunskapen. På ett övergripande plan visar studien att engagemang, påverkansmöjligheter och uthållighet är värden som överlappar mellan ungdomarnas olika livsåskådningar (oberoende av vad dessa för övrigt innehåller). Samtal om dessa värden i religionskunskapsundervisningen ger därmed möjlighet att: 1) resonera kring skillnader och likheter mellan olika livsåskådningar (Jackson 1997) i relation till hållbar utveckling; 2) visa på sambanden mellan hållbar utveckling, normer och makt (Martinson 2013); 3) låta eleverna öva upp sin förmåga att tolka och omvärdera sin egen livsåskådning i relation till andras och därmed skapa förutsättningar för mångfald och respekt (Jackson 1997), vilket krävs för en hållbar utveckling (WCED 1987, Agenda 2030, UNESCO 2017).

När det gäller erfarenheter av engagemang, makt och uthållighet på ett individuellt plan visar studien att ungdomarna förknippar dessa med samhörighet, jämlikhet och respekt. De senare utgör också delar av den sociala dimensionen av hållbar utveckling. I en etisk reflektion över handlandet (moralen) tillsammans med ungdomarna kan läraren uppmärksamma hur såväl sopsortering som viljan 
att hjälpa andra kräver både engagemang och uthållighet. Vidare kan elevernas starka upplevelser av och längtan efter samhörighet relateras till begreppet och fenomenet solidaritet. Deras förväntan på jämlikhet kan i sin tur relativt enkelt kopplas till respekt för mångfald (jmf von Brömssen 2003). På det viset kan undervisningen om hållbar utveckling i större grad anpassas till dessa individers erfarenheter och därmed göra den begriplig, relevant och meningsfull.

Studien visar således på några kopplingar mellan frågor som är viktiga för ungdomarna och hållbar utveckling (Rickinson 2001). Vidare kompletterar den tidigare forskning genom att visa hur inte bara erfarenheter av oro (Rickinson, Lundholm \& Hopwood 2009, Ojala 2016) utan också av engagemang, makt och uthållighet kan bidra till lärande om hållbar utveckling. Detta när de används som en ingång till att problematisera livsåskådningar. Erfarenheter av engagemang, makt och uthållighet är med andra ord en viktig resurs för såväl lärandet om hållbar utveckling som lärandet om olika livsåskådningar, där den sociala dimensionen av hållbar utveckling kan bidra till förståelsen och utvecklingen av ungdomarnas egen livsvärld och vice versa. Med andra ord finns det goda skäl för att låta religionskunskapsundervisningen inkludera undervisning för hållbar utveckling i gymnasiet, även om kursplanen för religionskunskap i den svenska gymnasieskolan (Religionskunskap Lgy11) inte ger stöd för det.

\section{ERKÄNNANDE}

Författaren vill uttrycka sin tacksamhet till Vetenskapsrådet för ekonomiskt stöd.

\section{LITTERATUR}

Agenda 2030. Att förändra vår värld: Agenda 2030 för hållbar utveckling. Regeringskansliet. Bråkenhielm, Carl Reinhold, Essunger, Maria och Westerlund, Katarina. 2013. «Att studera livet enligt människan» i C. R. Bråkenhielm, M. Essunger och K. Westerlund (red.), Livet enligt människan. Om livsåskådningsforskning. Nora: Nya Doxa.

Collins-Mayo, S. och Dandelion, P. (red.). 2010. Religion and Youth. Farnham: Ashgate. Collste, G. 2010. Inledning till etiken. Lund: Studentlitteratur.

Day, Abby. 2009. «Believing in Belonging: An Ethnography of Young People's Constructions of Belief» i Culture and Religion (10)3, 263-278.

Foucault, Michel. [1971] 1993. Diskursens ordning, Stockholm/Stehag: Brutus Östlings Bokförlag.

Figueroa, Robert \& Mills, Claudia. 2003. «Environmental Justice» i D. Jamieson

(red.), A Companion to Environmental Philosophy.

Illisko, D., Skrinda, A. \& Micule, I. 2014. «Envisioning the Future: Bachelor's and Master's Degree Students' Perspective. Journal of Teacher Education for Sustainability, 16(2), 88-102. 
Jackson, R. 2016. «A Retrospective Introduction to Religious Education: An Interpretative Approach» i Discourse and Communication for Sustainable Education, vol. 7, nr. 1, 149-160.

Jackson, R. 1997. Religious Education - an interpretative approach. London: Hodder \& Stoughton.

Karlsson Minganti, P. 2007. Muslima. Islamisk väckelse och unga muslimska kvinnors förhandlingar om genus i det samtida Sverige. Stockholm: Carlssons.

Kvale Steinar och Brinkman Svein. 2014. Den kvalitativa forskningsintervjun. Tredje uppl. Lund: Studentlitteratur.

Lgr11. 2011. Läroplanen för grundskola, förskoleklass och fritidshemmet 2011. Skolverket. www.skolverket.se

Lgy11. 2011. Läroplanen för gymnasieskolan. Skolverket. www.skolverket.se

Lindfelt, Mikael. 2003. Att förstå livsåskådningar: en metateoretisk analys av teologisk livsåskådningsforskning med anknytning till Anders Jeffners ansatser. Uppsala: Uppsala universitet.

Lindgren, M., Bernhard, L. och Fürth, T. 2005. The MeWe Generation. What business and politics must know about the new generation. Stockholm: Bookhouse publishing.

Lundegård, Iann. 2007. På väg mot pluralism: elever $i$ situerade samtal kring hållbar utveckling. Stockholm: HLS.

Löfstedt, M. 2013. «Livsfrågornas betydelse för religionsundervisningen» i C. R. Bråkenhielm, M. Essunger och K. Westerlund (red.), Livet enligt människan. Om livsåskådningsforskning. Nora: Nya Doxa.

Löfstedt, M. 2011. «Etik, moral och det goda livet» i M. Löfstedt (red.) Religionsdidaktik - mångfald, livsfrågor och etik i skolan. Lund: Studentlitteratur.

Lövheim, Mia. 2012. «Ungas religiositet: tidigare forskning och nya frågor» i $M$. Lövheim och J. Bromander (red.), Religion som resurs? Existentiella frågor och värderingar i unga svenskars liv. Skellefteå: Artos.

Martinson, Mattias. 2013. «Livsåskådningsforskning och systematisk teologi» i C. R. Bråkenhielm, M. Essunger och K. Westerlund (red.), Livet enligt människan. Om livsåskådningsforskning. Nora: Nya Doxa.

Ojala, Maria. 2016. «Facing anxiety in climate change education: From therapeutic practice to hopeful transgressive learning» i Canadian Journal of Environmental Education, 21, 41-56.

Religionskunskap Lgr11. 2011. Kursplanen i religionskunskap. Grundskolan. Skolverket. www.skolverket.se

Religionskunskap Lgy11. 2011. Kursplanen i religionskunskap. Gymnasieskolan. Skolverket. www.skolverket.se

Rickinson, Mark. 2001. «Learners and learning in environmental education. A critical review of evidence» i Environmental Education Research, 8 (1),43-51. 
Rickinson, M., Lundholm, C. och Hopwood, N. 2009. Environmental learning. Insights From Research Into the Student Experience. Netherlands: Springer.

Risenfors, S. 2011 Gymnasieungdomars livstolkande. Acta Universitatis Gothoburgensis. Göteborg: Göteborgs universitet.

Smith, C. och Lundquist Denton, M. 2005. Soul searching: The religious and spiritual lives of American Teenagers. New York: Oxford University Press.

UNESCO. 2017. Education for Sustainable Development. https://en.unesco.org/themes/ education-sustainable-development.

Warren, Karen J. 2000. Ecofeminist Philosophy: A Western Perspective on What it is and Why it Matters. Oxford: Rowman and Littlefield Publishers.

WCED 1987. Brundtland Commission. Our common future. Milton Keynes: Open University Press.

von Brömssen, K. 2003. Tolkningar, förhandlingar och tystnader: Elevers tal i det mångkulturella och postkoloniala rummet. Göteborg: Acta Universitatis Gothourgensis.

von Essen, Johan \& Grosse, Julia. 2012. «Senmodernitetens religiositet och ideella engagemang» i M. Lövheim och J. Bromander (red.), Religion som resurs? Existentiella frågor och värderingar i unga svenskars liv. Skellefteå: Artos.

Öhman, Johan och Östman, Leif. 2007. «Continuity and Change in Moral Meaningmaking - a Transactional Approach» i Journal of Moral Education, 36(2),151-168. 